\title{
Laparoscopic management of caesarean scar ectopic pregnancy: a case report
}

\section{Nazer Thalamkandathil*, Rasheeda Beegum, Beegum Hasooriya}

\author{
Department of Gynecology \& Obstetrics, Malabar Institute of Medical Sciences, PO Govindapuram, Calicut-673016 \\ Kerala, India
}

Received: 13 March 2015

Accepted: 19 April 2015

\section{*Correspondence: \\ Dr. Nazer Thalamkandathil, \\ E-mail: nazerdr@gmail.com}

Copyright: (C) the author(s), publisher and licensee Medip Academy. This is an open-access article distributed under the terms of the Creative Commons Attribution Non-Commercial License, which permits unrestricted non-commercial use, distribution, and reproduction in any medium, provided the original work is properly cited.

\begin{abstract}
A 30-year-old G5P2A2 woman was diagnosed to have ectopic pregnancy at the caesarean scar site on routine ultrasound scan followed by Doppler blood flow evaluation. It was managed successfully by laparoscopic resection. Ectopic pregnancy in a caesarean scar is a rare entity. It is important to diagnose the condition as early as possible in order to administer appropriate, timely treatment and to avoid complications. The optimal treatment of caesarean section scar ectopic pregnancies is unknown successfully by laparoscopic resection followed by endosuturing and this enabled uterine preservation.
\end{abstract}

Keywords: Caesarean section, Ectopic pregnancy, Laparoscopy

\section{INTRODUCTION}

Ectopic pregnancy in a caesarean scar is rare with an incidence of one in 2000 pregnancies and it constitutes about $5 \%$ of ectopic pregnancies. Pain and bleeding are the most common presenting symptoms, but up to $40 \%$ women are asymptomatic., ${ }^{1,2}$ Complications, such as uterine rupture and massive hemorrhage, may be lifethreatening and impact negatively on future fertility. Management options include methotrexate treatment, curettage, hysteroscopic resection, resection by laparotomy/laparoscopy and hysterectomy. Here we describe a case of ectopic pregnancy in a caesarean scar which was successfully managed by laparoscopic resection

\section{CASE REPORT}

A 30-year-old G5P2L2A2 woman came to us for a second opinion to rule out scar ectopic. She was asymptomatic and was diagnosed to have scar ectopic in a routine scan. She had evacuation in her $1^{\text {st }}$ and $4^{\text {th }}$ pregnancy for miscarriage. She had 2 caesarean sections as well.

Initial ultrasonography showed a gestational sac of 6 weeks +3 days with implantation at the scar site.

A 3D scan was done for her that showed a live ectopic pregnancy at the scar site with the sac only $1.3 \mathrm{~mm}$ away from the uterine serosa. Color Doppler showed decidual vascularity up to and along the serosal layer. On hysteroscopy, increased vascularity was noted at the left lateral aspect of anterior uterine wall and laparoscopy revealed a uterus of 6 weeks size with the anterior surface densely adherent to anterior abdominal wall and omental adhesion on lateral side. On releasing the adhesions and incising the uterovescical fold, bladder was pushed down and the ectopic sac began to pop out from the left side of the caesarean scar. Vasopressin 20 units in $150 \mathrm{ml}$ of saline was injected around the scar site to avoid bleeding. The defect in the scar was extended and the ectopic sac 
was removed in toto with hydro dissection. The incision was sutured endoscopically using 2.0 polyglactin 910 in one layer. Histopathology revealed blood clots with necrotic villi which was consistent with ectopic pregnancy. The patient was discharged on the third postoperative day after an uneventful recovery. Serum beta hCG value came down from the preoperative level of $19878 \mathrm{mIU} / \mathrm{ml}$ to $110 \mathrm{mIU} / \mathrm{ml}$ by $10^{\text {th }}$ post-operative day, Patient turned up for follow up after 8 weeks with a normal beta hCG value.

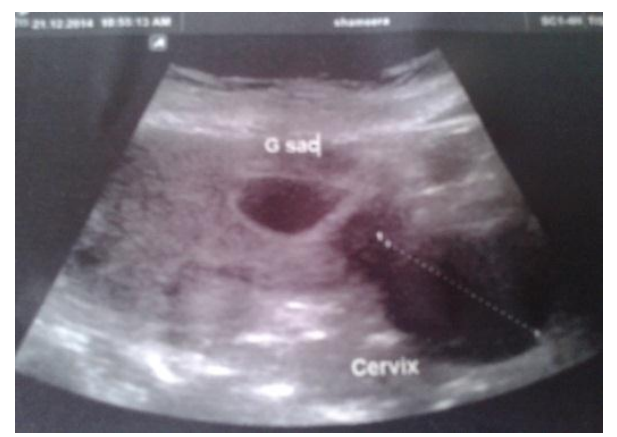

Figure 1: Trans vaginal ultrasound showing gest sac, lying in the lower uterine segment.

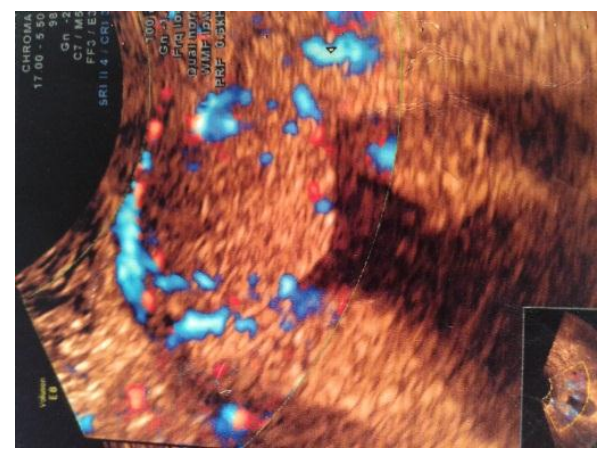

Figure 2: Doppler blood flow up to and along the serosal layer.

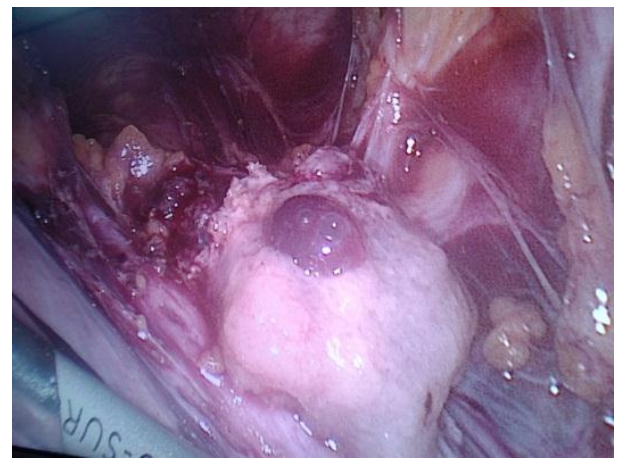

Figure 3: Gestational sac with decidua popping out of the scar.

\section{DISCUSSION}

Proposed ultrasound diagnostic criteria, allowing a differential diagnosis with cervical ectopic pregnancy, are: (i) A gestational sac located between the bladder wall and the anterior isthmic portion of the uterus; (ii) No trophoblastic tissue visible in the uterine cavity and cervical canal; and (iii) Clearly visible circular blood flow surrounding the sac. ${ }^{3}$ The immediate complications of caesarean scar pregnancy are uterine rupture, severe bleeding, need for hysterectomy, and maternal morbidity. Treatment standards are lacking but options include Dilatation and curettage, local and/or systemic methotrexate administration and excision of trophoblastic tissues using laparotomy or laparoscopy. ${ }^{4}$ Uterine artery embolization may be used adjunctively to minimize haemorrhage risk. ${ }^{5}$

\section{CONCLUSION}

Pregnancy in a previous caesarean section scar is the rarest kind of all ectopic pregnancies and probably one of the most dangerous because of the risk of rupture and hemorrhage. No treatment modality is entirely reliable, and none can guarantee uterine integrity. In this case, ultrasonography and Doppler blood flow together with hysterolaparoscopy proved to be a reliable method for diagnosing and managing ectopic pregnancy in a previous Caesarean section scar and it enabled uterine preservation

Funding: No funding sources

Conflict of interest: None declared

Ethical approval: Not required

\section{REFERENCES}

1. Sadeghi H, Rutherford T, Rackow BW. Caesarean scar ectopic pregnancy. Case reviews of literature Am J Perinatol. 2010;27(2):111.

2. Rotas MA, Haberman S, Levgur M. Cesarean scar ectopic pregnancies: etiology, diagnosis, and management. Obstet Gynecol. 2006;107:1373-81.

3. Vial Y, Petignat P, Hohlfeld P. Pregnancy in a cesarean scar. Ultrasound Obstet Gynecol. 2000;16:592-3.

4. Chyi-Long Lee, Chin-Jung Wang, Angel Chao. Laparoscopic management of ectopic pregnancy in a previous caesarean scar. Hum Reprod. 1999;14(5):1234-6.

5. Zhuang Y, Hyang L. Uterine artery embolization compared with Methotrexate for the management of pregnancy implanted within caesarean section scar Am J Obstet Gynecol. 2009;49(5):451.

DOI: $10.18203 / 2320-1770 . i j \operatorname{rog} 20150114$

Cite this article as: Thalamkandathil N, Beegum R, Hasooriya B. Laparoscopic management of caesarean scar ectopic pregnancy: a case report. Int J Reprod Contracept Obstet Gynecol 2015;4:871-2. 